\title{
Where Do Betas Come From? Asset Price Dynamics and the Sources of Systematic Risk
}

\section{Citation}

Campbell, John Y., and Jianping Mei. 1993. Where do betas come from? Asset price dynamics and the sources of systematic risk. Review of Financial Studies 6(3): 567-592.

\section{Published Version}

http://dx.doi.org/10.1093/rfs/6.3.567

\section{Permanent link}

http://nrs.harvard.edu/urn-3:HUL.InstRepos:3353757

\section{Terms of Use}

This article was downloaded from Harvard University's DASH repository, and is made available under the terms and conditions applicable to Other Posted Material, as set forth at http:// nrs.harvard.edu/urn-3:HUL.InstRepos:dash.current.terms-of-use\#LAA

\section{Share Your Story}

The Harvard community has made this article openly available.

Please share how this access benefits you. Submit a story.

Accessibility 


\title{
NBER WORKING PAPER SERIES
}

\author{
WHERE DO BETAS \\ COME FROM? ASSET PRICE \\ DYNAMICS AND THE SOURCES \\ OF SYSTEMATIC RISK
}

\author{
John Y. Campbell \\ Jianping Mei
}

Working Paper No. 4329

\section{NATIONAL BUREAU OF ECONOMIC RESEARCH \\ 1050 Massachusetts Avenue \\ Cambridge, MA 02138 \\ April 1993}

This paper is part of NBER's research program in Asset Pricing. Any opinions expressed are those of the authors and not those of the National Bureau of Economic Research. 
NBER Working Paper \#4329

April 1993

\title{
WHERE DO BETAS \\ COME FROM? ASSET PRICE \\ DYNAMICS AND THE SOURCES \\ OF SYSTEMATIC RISK
}

\begin{abstract}
This paper breaks assets' betas with common factors into components attributable to news about future cash flows, real interest rates, and excess returns. To achieve this decomposition the paper uses a vector autoregressive time-series model and an approximate log-linear present value relation. The betas of industry and size portfolios with the market are largely attributed to changing expected returns. Betas with inflation and industrial production reflect opposing cash flow and expected return effects. The paper also shows how asset pricing theory restricts the expected excess return components of betas.
\end{abstract}

John Y. Campbell

Woodrow Wilson School

Princeton University

Robertson Hall

Princeton, NJ 08544

and NBER
Jianping Mei

Department of Finance

Stern School of Business

New York University

44 West 4th Street

New York, NY 10012

(212) 998-0354 


\section{WHERE DO BETAS COME FROM?}

\section{ASSET PRICE DYNAMICS AND THE SOURCES OF SYSTEMATIC RISK*}

Betas, or sensitivities of asset returns to underlying sources of risk, are central to modern finance. Betas are used by academics and practitioners to model and control systematic risks. Betas also determine expected asset returns in the Capital Asset Pricing Model (CAPM) of Sharpe (1964) and Lintner (1965) and its descendants such as the Intertemporal CAPM of Merton (1973) and the Arbitrage Pricing Theory of Ross (1976).

Given their importance, it is natural to ask how betas are determined. Campbell and Shiller (1988) and Campbell (1991) have shown that unexpected returns can be written as an approximate linear function of changing expectations of future cash flows, real interest rates, and excess returns. They obtain this result by taking a loglinear approximation to an accounting identity, so the result is not conditional on the validity of any particular asset pricing model. Since betas are scaled covariances of returns with sources of risk, the Campbell-Shiller decomposition implies that betas depend on the covariances of news about cash flows, real interest rates, and future excess returns with sources of risk. In this paper we make a first attempt to estimate the relative importance of these beta components. ${ }^{1}$

If one is willing to impose an asset pricing model, then it is possible to go further than this. An asset pricing model derives expected excess returns from betas and market prices of risk. Thus by imposing an asset pricing model one can substitute out the components of betas that are related to expected future excess returns. One can then show how the underlying covariances of assets' cash flows with sources of risk determine their betas. We carry out this exercise for the CAPM, and briefly discuss more general models.

Our work bridges a gap between two common modes of analysis in empirical finance: cross-sectional analysis of multi-factor models, and fundamental analysis using the present value relation. The former analysis breaks risk down into sensitivities to various factors, while the latter distinguishes between cash flow risk and discount rate risk. Here we combine these two models, using both contemporaneous cross-sectional information and time-series information to describe the dynamic behavior of asset returns. 
The organization of the paper is as follows. In Section 1 we explain our theoretical framework and show how time-series econometric methods can be used to construct empirical proxies for the various components of betas. In Section 2 we decompose betas of industry and size portfolios into cash flow, real interest rate, and excess return components. Section 3 explores the restrictions on excess return components implied by asset pricing models with constant betas. Section 4 concludes. 


\section{Where Betas Come From: A Theoretical Framework}

\subsection{The Campbell-Shiller Approximation}

In general stock prices and returns are affected by changing expectations about both dividends and required returns. The difficulty is that the standard present value relation is nonlinear when expected returns vary through time. This makes it intractable except in a few special cases.

Campbell and Shiller (1988) propose a log-linear approximation to the standard model. They argue that the approximation is both tractable and surprisingly accurate. We follow Campbell (1991) and define the one-period log real holding return on stock $i$ as $h_{i, t+1} \equiv \log \left(P_{i, t+1}+D_{i, t+1}\right)-\log \left(P_{i, t}\right)$, where $P_{i, t}$ is the real stock price measured at the end of period $t$ (ex dividend), and $D_{i, t}$ is the real dividend paid during period $t$. The right hand side of this identity is a nonlinear function of the log stock price and the log dividend; it can be approximated, using a first-order Taylor expansion, as

$$
h_{i, t+1} \approx k+\rho p_{i, t+1}+(1-\rho) d_{i, t+1}-p_{i, t}
$$

where lower-case letters are used for logs. The parameter $\rho$ comes from the linearization and is a number slightly smaller than one, while the constant $k=-\log (\rho)-$ $(1-\rho) \log (1 / \rho-1)$. Equation (1) replaces the $\log$ of the sum of price and dividend with a weighted average of $\log$ price and $\log$ dividend. Intuitively, the future log stock price gets a larger weight than the future log dividend because a given percentage change in the stock price is absolutely larger than the same percentage change in the dividend.

When the log holding return on stock is linearized around the mean log dividendprice ratio $d-p$, the parameter $\rho=1 /(1+\exp (d-p))$. In this paper we linearize the $\log$ returns on all assets around a common mean $\log$ dividend-price ratio, so that $\rho$ is the same for all assets. This forces all asset returns to be equally sensitive to changes in real interest rates. In practice our results are robust to variations in $\rho$ within a plausible range, so the use of a common $\rho$ across assets should not be too problematic.

Equation (1) can be thought of as a difference equation relating $p_{i, t}$ to $p_{i, t+1}, d_{i, t+1}$ and $h_{i, t+1}$. It holds ex post, but it also holds ex ante as an expectational difference equation. Campbell and Shiller impose the terminal condition that $\lim _{j \rightarrow \infty} E_{t} \rho^{j} p_{i, t+j}=0$. 
This condition rules out "rational bubbles" that would cause explosive behavior of the log stock price. With this terminal condition, the ex ante version of (1) can be solved forward to obtain

$$
p_{i, t}=\frac{k}{1-\rho}+(1-\rho) E_{t} \sum_{j=0}^{\infty} \rho^{j} d_{i, t+1+j}-E_{t} \sum_{j=0}^{\infty} \rho^{j} h_{i, t+1+j}
$$

This equation is useful because it enables one to calculate the effect on the stock price of a change in expected stock returns. It says that the log stock price $p_{i, t}$ can be written as a constant $k /(1-\rho)$ plus the expected discounted value of all future dividends $d_{i, t+1+j}$ less future returns $h_{i, t+1+j}$, discounted at the constant rate $\rho$. If the stock price is high today, this must mean that future expected dividends are high unless returns are expected to be low in the future. Note that (2) is not an economic model, but has been derived by approximating an identity and imposing a terminal condition. It is best thought of as a consistency condition that must be satisfied by any reasonable set of expectations.

Campbell (1991) uses equation (2) to substitute $p_{i, t}$ and $p_{i, t+1}$ out of (1). This gives a decomposition of the unexpected stock return or stock return innovation, which we write as $\tilde{h}_{i, t+1}$ :

$$
\begin{aligned}
\tilde{h}_{i, t+1} & \equiv h_{i, t+1}-E_{t} h_{i, t+1} \\
& =\left(E_{t+1}-E_{t}\right)\left\{\sum_{j=0}^{\infty} \rho^{j} \Delta d_{i, t+1+j}-\sum_{j=1}^{\infty} \rho^{j} h_{i, t+1+j}\right\} .
\end{aligned}
$$

Once again, this equation should be thought of as a consistency condition for expectations. If the unexpected stock return is negative, then either expectations of future dividend growth must be revised downwards, or expectations of future stock returns must be revised upwards, or both. There is no behavioral model behind (3); it is simply an approximation to an identity.

The formulas above concern real log stock returns, but in this paper we work with excess log stock returns over a short-term interest rate. We define $e_{i, t+1} \equiv h_{i, t+1}-r_{t+1}$, 
where $r_{t+1}$ is the real return on a 1 -month Treasury bill. We use $\tilde{e}_{i, t+1}$ to denote the innovation in $e_{i, t+1}$. Then

$$
\begin{aligned}
\tilde{e}_{i, t+1} & =\left(E_{t+1}-E_{t}\right)\left\{\sum_{j=0}^{\infty} \rho^{j} \Delta d_{i, t+1+j}-\sum_{j=0}^{\infty} \rho^{j} r_{t+1+j}-\sum_{j=1}^{\infty} \rho^{j} e_{i, t+1+j}\right\} \\
& =\tilde{e}_{d i, t+1}-\tilde{e}_{r, t+1}-\tilde{e}_{e i, t+1} .
\end{aligned}
$$

The second equality in (4) introduces simpler notation for the components of the unex-

pected excess stock return $\tilde{e}_{i, t+1}$. The variable $\tilde{e}_{d i, t+1}$ represents revisions in expected future dividends or news about future dividends on asset $i$, while $\bar{e}_{r, t+1}$ is news about future real interest rates and $\tilde{e}_{e i, t+1}$ is news about future excess returns on asset $i$.

Equations (1) to (4) hold only as approximations, but in the remainder of this paper we treat them as exact. Campbell and Shiller (1988) studies approximation error in (1) and (2), while an Appendix to this paper, available from the authors on request, studies approximation error in (3) and (4). In all these equations the approximation error seems to be small enough for U.S. stock market data that it should have no important effect on our results.

\subsection{A Beta Decomposition}

In this paper we define beta using unconditional variances and covariances of innovations in returns and factors. That is, we study the unconditional covariance of the return innovation with a factor innovation, divided by the unconditional variance of the factor innovation. This is neither a full conditional beta (which would use conditional variances and covariances), nor a straightforward unconditional beta (which would use returns themselves rather than innovations in returns). Beta as defined here has the advantage that it can be broken into components in a relatively simple way. If all elements of the conditional variance-covariance matrix of innovations are constant or changing in proportion to one another, then our beta equals the full conditional beta. Under these conditions asset pricing theory can be used in a deeper analysis of beta; we discuss this later in the paper, but for the present we simply take our beta as a useful summary measure of an asset's sensitivity to a factor. 
The most familiar type of beta is a market beta. Our definition of market beta is

$$
\beta_{i, m} \equiv \frac{\operatorname{Cov}\left(\tilde{e}_{i}, \tilde{e}_{m}\right)}{\operatorname{Var}\left(\tilde{e}_{m}\right)}
$$

Here $\tilde{e}_{i}$ is the unexpected excess return on asset $i$ and $\tilde{e}_{m}$ is the unexpected excess return on the market. (For notational simplicity we suppress time subscripts on these and similar variables wherever possible.) Equation (4) allows us to decompose $\beta_{i, m}$ as

$$
\begin{aligned}
\beta_{i, m} & =\frac{\operatorname{Cov}\left(\tilde{e}_{d i}, \tilde{e}_{m}\right)}{\operatorname{Var}\left(\tilde{e}_{m}\right)}-\frac{\operatorname{Cov}\left(\tilde{e}_{r}, \tilde{e}_{m}\right)}{\operatorname{Var}\left(\tilde{e}_{m}\right)}-\frac{\operatorname{Cov}\left(\tilde{e}_{e i}, \tilde{e}_{m}\right)}{\operatorname{Var}\left(\tilde{e}_{m}\right)} \\
& =\beta_{d i, m}-\beta_{r, m}-\beta_{e i, m},
\end{aligned}
$$

where $\beta_{d i, m}$ is the market beta of news about asset $i$ 's future cash flows, $\beta_{r, m}$ is the market beta of news about future real interest rates, and $\beta_{e i, m}$ is the market beta of news about asset i's future excess returns.

More generally, one may want to work with $K$ common factors in asset returns. Our definition of beta with the $k^{\prime}$ th factor $\tilde{f}_{k}$ is

$$
\beta_{i, k} \equiv \frac{\operatorname{Cov}\left(\tilde{e}_{i}, \tilde{f}_{k}\right)}{\operatorname{Var}\left(\tilde{f}_{k}\right)}
$$

Equation (4) allows us to decompose this beta as follows:

$$
\begin{aligned}
\beta_{i, k} & =\frac{\operatorname{Cov}\left(\tilde{e}_{d i}, \tilde{f}_{k}\right)}{\operatorname{Var}\left(\tilde{f}_{k}\right)}-\frac{\operatorname{Cov}\left(\tilde{e}_{r}, \tilde{f}_{k}\right)}{\operatorname{Var}\left(\tilde{f}_{k}\right)}-\frac{\operatorname{Cov}\left(\tilde{e}_{e i}, \tilde{f}_{k}\right)}{\operatorname{Var}\left(\tilde{f}_{k}\right)} \\
& =\beta_{d i, k}-\beta_{r, k}-\beta_{e i, k} .
\end{aligned}
$$

Equations (6) and (8) give the basic decomposition we use in our empirical work. 


\subsection{Empirical Proxies for Beta Components}

In order to implement our beta decomposition, we need to construct empirical proxies for news about future cash flows, excess returns, and real interest rates. To do this, we assume that we observe $N$ excess returns over a 1 -month Treasury bill return. The first excess return is on the value-weighted market portfolio of stocks. We postulate that expectations of these excess returns are linear in a vector of state variables $x_{t}$ with $L$ elements $x_{l t}, l=1 \ldots L$. The first of these elements is the excess return on the market and the second is the real return on a 1-month Treasury bill, while the other elements are variables known to the market by the end of period $t$. Thus the excess return on any asset can be written as

$$
e_{i, t+1}=a_{i}^{\prime} x_{t}+\tilde{e}_{i, t+1}
$$

for some $L$-element column vector $a_{i}$. The expected excess return on the market is given by $a_{1}^{\prime} x_{t}$, and the unexpected excess return on the market is $\bar{e}_{1, t+1}$.

Next we assume that the state vector follows a first-order VAR:

$$
x_{t+1}=\Pi x_{t}+\tilde{x}_{t+1} \text {, }
$$

where we again use the notational convention that $\tilde{x}_{t+1}$ is the innovation in $x_{t+1}$. The assumption that the VAR is first-order is not restrictive since a higher-order VAR can always be rewritten in first-order form as discussed by Campbell and Shiller (1988) among others. The matrix $\Pi$ is known as the companion matrix of the VAR. The assumptions we have made imply that $a_{1}^{\prime}$ is the first row of $\Pi$. Given the VAR model, revisions in long-horizon expectations of $x_{t+1}$ are:

$$
\left(E_{t+1}-E_{t}\right) x_{t+j+1}=\Pi^{j} \tilde{x}_{t+1}
$$

Finally, we define $\iota_{2}$ to be an $L$-element column vector whose second element is one and whose other elements are all zero. This vector picks the real interest rate out 
of the state vector. Then equation (11) and the definitions of $\tilde{e}_{d i}, \tilde{e}_{r}$ and $\tilde{e}_{e i}$ in (4) imply that the components of asset returns can be written as follows:

$$
\begin{aligned}
\tilde{e}_{e m} & =\rho a_{1}^{\prime}(I-\rho \Pi)^{-1} \tilde{x}_{t+1}, \\
\tilde{e}_{d m} & =\tilde{e}_{1, t+1}+\left(\iota_{2}^{\prime}+\rho a_{1}^{\prime}\right)(I-\rho \Pi)^{-1} \tilde{x}_{t+1}, \\
\tilde{e}_{r} & =\iota_{2}^{\prime}(I-\rho \Pi)^{-1} \tilde{x}_{t+1}, \\
\tilde{e}_{e i} & =\rho a_{i}^{\prime}(I-\rho \Pi)^{-1} \tilde{x}_{t+1}, \\
\tilde{e}_{d i} & =\tilde{e}_{i, t+1}+\left(\iota_{2}^{\prime}+\rho a_{i}^{\prime}\right)(I-\rho \Pi)^{-1} \tilde{x}_{t+1} .
\end{aligned}
$$

Innovations in expected future excess returns and cash flows are determined by innovations $\tilde{x}$ to the economic state variables, by the matrix $\Pi$ governing the evolution of the state variables, by the vectors $a_{i}$ which map state variables to expected returns, and by unexpected asset returns $\tilde{e}_{i, t+1}$. The term $(I-\rho \Pi)^{-1} \tilde{\mathcal{I}}_{t+1}$ which appears in the above expressions represents the revision at time $t+1$ in the discounted multi-period forecast of the state vector into the infinite future. Appropriate elements are taken from this state vector forecast revision to form the components of asset returns.

Once we have the asset return components above, it is straightforward to take ratios of covariances to variances to construct betas. In our empirical work we look at betas with the innovations in the economic state variables $\tilde{x}_{t+1}$. That is, we use state variable innovations as factors, as in Chen, Roll, and Ross (1986) or Ferson (1990). The innovation in the market return is just the first element of $\tilde{x}_{t+1}$. When we need the factors to be orthogonal, we can orthogonalize the vector of VAR innovations in the manner of Sims (1980). 


\section{Empirical Results}

\subsection{Data and Econometric Methods}

In this section we apply our methods to study the systematic risks of industry and size portfolios. The industry portfolios are twelve value-weighted portfolios constructed using two-digit SIC codes. The size portfolios are ten value-weighted portfolios based on size deciles using the market value of equity outstanding at the beginning of each year. ${ }^{2}$

We use several aggregate variables as the elements of the state vector. The first two elements must be the market excess return and the real interest rate. The remaining variables are the dividend yield on the market portfolio, the inflation rate, and the growth rate of industrial production. Our measure of the market return is the return on the value-weighted New York Stock Exchange (NYSE) index. The dividend yield on this index is calculated in standard fashion by taking total dividends paid over the previous year relative to the current stock price. The real interest rate is the onemonth treasury bill rate less the CPI inflation rate, where both these variables are Ibbotson Associates data series provided by the Center for Research in Security Prices (CRSP). The seasonally-adjusted monthly real industrial production index is taken from the Citibase tape. Our sample covers the time period from 1952:1 to 1987:12. Following Campbell (1991) we set $\rho=0.9962$, which corresponds to an annual mean dividend-price ratio of $4.7 \%$.

To estimate the parameters in equations (9) and (10), and to calculate the variancecovariance matrix of their error vectors, we estimate (9) and (10) jointly across all portfolios and state variables, using Hansen's (1982) Generalized Method of Moments. Let us denote the entire set of parameters $\gamma$, and the variance-covariance matrix of these parameters $V$. To calculate a standard error for a statistic such as the cash flow beta, we write the statistic as a nonlinear function $f(\gamma)$ of the parameter vector $\gamma$. The standard error for the statistic can be estimated in standard fashion as $\sqrt{f_{\gamma}(\gamma)^{\prime} V f_{\gamma}(\gamma)}$.

In our empirical work, we have tried two variants of this basic estimation procedure. The first variant allows for sampling error both in the parameters of equations (9) and (10) and in the covariances between $\tilde{e}_{i, t+1}$ and $\tilde{x}_{t+1}$. This requires that we treat the covariances, $\Omega$, as parameters of the model, so the number of parameters to be estimated increases very rapidly with the VAR lag length. Accordingly we have only implemented this variant of our procedure with one VAR lag. 
The second variant takes account only of sampling error in the parameters of equations (9) and (10). In effect, the covariances between $\tilde{e}_{i, t+1}$ and $\tilde{x}_{t+1}$ are treated as known. One could think of this variant as analyzing sample betas rather than population betas. This procedure significantly reduces the number of parameters to be estimated, allowing us to explore higher-order VAR systems.

We have found that our empirical results are similar whichever variant of our method we use, and for the second variant are insensitive to VAR lag length. Thus we present our beta decomposition results using the first variant of our method with a first-order VAR system.

\subsection{A Beta Decomposition for Industry Portfolios}

Table 1 studies the betas of industry portfolios with the aggregate stock market. The first column of the table shows the overall market beta for each portfolio. This is decomposed in the second and third columns into market betas of cash flow news and excess return news, $\beta_{d i, m}$ and $\beta_{e i, m}$. The future real interest rate beta, $\beta_{r, m}$, is estimated to equal 0.012 over this sample period as reported at the bottom of Table 1. Thus the second column of Table 1 shows the contribution to each portfolio's market beta of news about its cash flows. The negative of the third column shows the contribution to each portfolio's market beta of news about its future expected excess returns.

Several features of Table 1 are worth noting. First, the absolute values of excess return betas are always much larger than the absolute values of cash flow betas. This reflects the fact, documented by Campbell (1991) and Campbell and Ammer (1993) for the aggregate stock market, that much of the variability in stock returns is associated with changing expected future excess returns.

Second, the estimated cross-sectional pattern of cash flow betas is quite reasonable. Cyclical industries such as Basic Industries, Capital Goods, and Textiles have high cash flow betas whereas stable industries such as Utilities and Services have low (indeed slightly negative) cash flow betas. This pattern is not just a replication of the pattern of overall betas; Services, for example, is an industry with high overall beta but low cash flow beta. Our model attributes the high overall beta of this industry to the fact that its expected return is highly sensitive to market expected returns. It is important to note, however, that the standard errors for cash flow betas are always rather large. 
An alternative measure of cyclicality is the beta of an asset's cash flow news with the market's cash flow news (as opposed to the beta with the overall market return, which is also driven by news about future market returns). The last column of Table 1 presents estimates of this alternative beta. We use the notation $\beta_{d i, d m}$ to indicate that this is the sensitivity of news about future cash flows on asset $i, \tilde{e}_{d i}$, to news about future cash flows of the market, $\tilde{e}_{d m}$. We find that the cash flows of cyclical industries are more sensitive to changes in market cash flows; in fact, $\beta_{d i, d m}$ is always fairly close to the overall market beta of an industry. This result should be interpreted cautiously, however, as the standard errors for $\beta_{d i, d m}$ estimates are even larger than the standard errors for $\beta_{d i, m}$ estimates.

Since cash flows are a residual in our approach, one might suspect that portfolios with large cash flow betas in Table 1 are also portfolios whose excess returns are hard to forecast. The fifth column of Table 1 presents the $R^{2}$ statistic and the standard deviation of the fitted value for each excess return forecasting regression. There is no clear relationship between the forecastability of monthly excess returns and our estimates of cash flow and excess return betas; evidently the longer-run dynamics of the excess return forecasts, as captured by the VAR system, are critical in determining excess return betas.

Next we study the betas of the overall market and of industry portfolios with innovations in economic state variables. The left hand panel of Table 2 presents the estimated betas of news about cash flow with innovations in the real interest rate, the market dividend yield, the inflation rate, and the growth rate of industrial production. In each case betas are defined in the manner of equation (7) as covariances of asset returns with factors divided by factor variances, but we do not orthogonalize the factors.

The table shows that an unexpected increase in the ex post real interest rate is associated with a significant increase in expected future cash flows on almost all portfolios. Positive innovations in industrial production also increase expected future cash flows, although this effect is much weaker. Increases in the market dividend yield have no strong relationship with cash flow news, while increases in inflation rates are associated with downward revisions in expected future cash flows. The results for the real interest rate and for inflation are consistent with one another, since ex post real interest rate innovations are strongly negatively correlated with inflation innovations (and would in fact be perfectly correlated if we included the nominal interest rate in the VAR system). These results contradict the notion that real cash flows to holders 
of equity are insensitive to inflation. Of course, Fama and Schwert (1977) and many other authors have shown that stock returns are sensitive to inflation, but the cash flow component of stock returns has not been separately investigated.

The bottom row of Table 2 reports the beta of news about future real interest rates with innovations in the state variables. Future real interest rates rise with the current real interest rate and fall with the current inflation rate, but are only weakly associated with innovations in the dividend yield and industrial production.

The right hand panel of Table 2 presents the estimated betas of news about future expected excess returns with innovations in economic state variables. We can see that unexpected increases in the market dividend yield are strongly positively related to news about future expected excess returns. Other state variables are only weakly correlated with news about future excess returns.

Since the overall return beta with the innovation in a state variable, $\beta_{i, k}$, is just the cash flow beta less the real interest rate beta less the excess return beta, we can combine the different parts of Table 2 to get the implied values for $\beta_{i, k}$. For example, an unexpected $1 \%$ increase in the annual ex post real interest rate is associated with a $0.08 \%(0.20 \%-0.15 \%+0.03 \%)$ excess return on the aggregate market. For both the aggregate market and the individual portfolios, the positive impact of the real interest rate through increased cash flows and reduced future excess return outweighs the negative impact through increased future real interest rates. As one would guess, the effect of an inflation innovation is the opposite of the effect of an ex post real interest rate increase: When inflation goes up, stock returns are typically negative because the negative impact through cash flows and future excess returns outweighs the positive effect of declining future real interest rates. ${ }^{3}$ To put it another way, stock portfolios would be even more sensitive to inflation if real interest rates were constant.

The pattern of results for industrial production is also interesting. We find that the generally positive impact of industrial production growth on cash flow is largely offset by the negative impact of an increase in expected future excess returns. This explains the otherwise puzzling fact that good news about production growth has little impact on current stock returns. Our results enrich the story told by Chen (1991), who discovers that industrial production innovations are negatively correlated with current stock returns and positively correlated with expected future returns. Lacking any way to break returns into components, Chen is unable to relate his findings to the time-series behavior of equity cash flows. 


\subsection{A Beta Decomposition for Size Portfolios}

In Tables 3 and 4 we repeat the previous analysis for ten size portfolios. The first column of Table 3 shows the well-known fact that overall market betas on sizesorted portfolios decline almost monotonically with size. The second and third columns attribute this pattern mainly to the fact that expected future cash flows on small stocks are more sensitive to the market return. The betas for excess return news are not strongly related to size. The fourth column of Table 3 shows that the beta of cash flow news with market cash flow news generally declines with size, but the decline is not monotonic. Finally, the fifth column of Table 3 shows that small stocks typically have more variable expected excess returns, but this does not translate into expected excess return betas that are larger in absolute value for small stocks.

The left hand panel of Table 4 presents cash flow betas of size portfolios with innovations in economic state variables. We find that news about cash flows on small firms is generally more sensitive to unexpected changes in real interest rates and inflation. An unexpected $1 \%$ increase in the annualized real interest rate has a $0.38 \%$ positive cash flow effect on the smallest firm portfolio, but only a $0.15 \%$ positive cash flow effect on the next-to-largest firm portfolio and a $0.21 \%$ positive cash flow effect on the largest portfolio. Similarly, an unexpected $1 \%$ increase in the annual inflation rate has a $0.36 \%$ negative cash flow effect on the smallest portfolio, but a $0.17 \%$ negative effect on the next-to-largest portfolio and a $0.31 \%$ negative effect on the largest portfolio. This finding complements the study by Chan and Chen (1991), which examines differences in firms' structural characteristics that lead firms of different sizes to react differently to economic news. Chan and Chen find that firm size is highly correlated with firm characteristics such as entry type, financial ratios, leverage and dividend behavior. But Chan and Chen are not able to directly examine the relationship between a firm's size and its cash flow sensitivity to economic variables.

Finally, the bottom row and right hand panel of Table 4 give the sensitivity of news about real interest rates and future expected excess returns on size portfolios to economic variables. All the main results we obtained for industry portfolios appear again here. The cash flow effect of inflation outweighs the future real interest rate effect. And both cash flow effects and future excess return effects play a role in accounting for the cross-sectional variation in the overall betas on real interest rates and inflation. 


\subsection{Alternative Measures of Cash Flow News}

So far we have treated cash flow news as a residual component of the stock return. If equation (3) is an accurate approximation, and if the VAR system fully describes the true process for expected returns, then this residual calculation procedure should accurately measure cash flow news. However, if the VAR process used is misspecified, then the "residual cash flow news" measure may be a poor proxy for actual cash fiow news. To study this issue, we calculate an alternative "direct cash flow news" measure for the value-weighted NYSE stock price index.

The monthly dividend series is strongly seasonal, because most companies in the value-weighted stock index pay quarterly dividends. Simple seasonal adjustment procedures such as the use of seasonal dummies do not seem to remove the seasonality, so we use quarterly data over the period 1952:Q1-1987:Q4. We first form residual cash flow news by using the VAR procedure with quarterly values of the state variables. We adjust the value of $\rho$ for the change in the time unit of the data. We then form direct cash flow news by regressing quarterly log real dividend growth on the state variables and using the VAR process for the state variables to form revisions in expectations of future dividends. Specifically, if $c$ is the vector of regression coefficients of dividend growth on the state variables, and if the residual from this regression is $\mu_{t+1}$, then direct cash flow news is

$$
\tilde{e}_{d m}=\mu_{t+1}+\rho c^{\prime}(I-\rho \Pi)^{-1} \tilde{x}_{t+1}
$$

Table 5, panel $B$, reports the correlation between the residual and direct cash flow news measures as the monthly value of $\rho$ varies between 0.991 and 0.997 . This correlation always lies between 0.92 and 0.935 , and it increases with $\rho$. Panel A shows the residual and direct cash flow betas with the market return and the other factors considered in the paper. The residual and direct cash flow betas are always close to one another. The results in the table are based on a 1-lag VAR process. Results are generally similar for a 2-lag VAR process; however, the correlation between the residual and direct cash flow news measures drops from about 0.93 to about 0.88 . Results are also fairly similar if we include dividend growth in the state vector and recalculate both the residual and direct cash flow news measures. 
We conclude that the choice between the residual and direct measures of cash flow news is not critically important for our results. We use the residual measure in the rest of the paper because it enables us to avoid dealing with the seasonality in the dividend growth series. 


\section{Beta Determinants in Asset Pricing Models}

Under certain conditions asset pricing theory may impose that expected excess asset returns are proportional to betas as we have defined them. This will be true, for example, if expected excess returns are proportional to full conditional betas and if the variances and covariances of innovations are constant or changing in proportion to one another, so that conditional betas are constant and equal to our betas. ${ }^{4}$ Under these conditions asset pricing theory can be used to eliminate the expected excess return components from (6) and (8).

\subsection{The CAPM}

As a first example, consider the market beta decomposition given in (6). Suppose that the CAPM holds for our definition of market beta. Then expected excess returns in any future period are linear in beta:

$$
E_{t} e_{i, t+j+1}=\beta_{i, m} E_{t} e_{m, t+j+1}
$$

Using equations (4) and (14), we can calculate the news about future excess returns for asset $i$ at time $t+1$ :

$$
\begin{aligned}
\bar{e}_{e i} & \equiv\left(E_{t+1}-E_{t}\right) \sum_{j=1}^{\infty} \rho^{j} e_{i, t+j+1} \\
& =\left(E_{t+1}-E_{t}\right) \sum_{j=1}^{\infty} \rho^{j} E_{t+j}\left[\beta_{i, m^{e}} e_{m, t+j+1}\right] \\
& =\beta_{i, m} \tilde{e}_{e m},
\end{aligned}
$$

where $\bar{e}_{e m}$ is news about future excess returns on the market. Equation (15) says that if the CAPM holds, news about future excess returns on any stock equals that stock's beta times news about future excess returns on the market.

We can now use equation (15) to rewrite (6) as

$$
-16-
$$




$$
\beta_{i, m}=\frac{\operatorname{Cov}\left(\tilde{e}_{d i}-\tilde{e}_{r}, \tilde{e}_{m}\right)}{\operatorname{Var}\left(\tilde{e}_{m}\right)}-\beta_{i, m} \frac{\operatorname{Cov}\left(\tilde{e}_{e m}, \tilde{e}_{m}\right)}{\operatorname{Var}\left(\tilde{e}_{m}\right)}
$$

Solving for $\beta_{i, m}$ in the above equation, we have:

$$
\begin{aligned}
\beta_{i, m} & =\left[1+\frac{\operatorname{Cov}\left(\tilde{e}_{e m}, \tilde{e}_{m}\right)}{\operatorname{Var}\left(\tilde{e}_{m}\right)}\right]^{-1} \frac{\operatorname{Cov}\left(\tilde{e}_{d i}-\tilde{e}_{r}, \tilde{e}_{m}\right)}{\operatorname{Var}\left(\tilde{e}_{m}\right)} \\
& =\left(1+\beta_{e m, m}\right)^{-1}\left(\beta_{d i, m}-\beta_{r, m}\right),
\end{aligned}
$$

where $\beta_{e m, m}$ is the market beta of news about future excess returns on the market.

Equation (17) says that an asset's overall market beta is a linear function of the market beta of news about future cash flows on the asset. In Figures 1 and 2 this linear function is shown as a solid line. The intercept and slope in (17) depend on the market beta of news about real interest rates, $\beta_{r, m}$, and the market beta of news about future excess market returns, $\beta_{e m, m}$. Over the period 1952-87 we estimate $\beta_{r, m}$ to be very close to zero at 0.01 , while $\beta_{c m, m}$ is negative and quite large in absolute value at about -0.8. These estimates are similar to those implied by the results of Campbell (1991). The small estimate of $\beta_{r, m}$ reflects the fact that the stock market is much more volatile than real interest rates so the market beta of real interest rate news is close to zero. The size of $\beta_{e m, m}$ reflects the fact that much of the variation in stock returns is associated with changing expected future stock returns. Holding dividends and real interest rates fixed, a higher expected future return requires a lower stock price today, hence the negative sign of $\beta_{c m, m}$.

The effect of $\beta_{r, m}$ in (17) is common to all assets, reflecting the common influence of real interest rate variation on all long-term returns. ${ }^{5}$ To see the role of $\beta_{r, m}$ in determining individual assets' market betas, consider a stock whose cash flows have a positive market beta $\beta_{d i, m}$ exactly equal to $\beta_{r, m}$. When the market rises, good cash flow news tends to increase the price of this stock but higher real interest rates tend to reduce the price of the stock. Overall, the stock has zero covariance with the market.

The slope coefficient $\left(1+\beta_{e m, m}\right)^{-1}$ in equation (17) has a more important influence on assets' overall market betas. If $\beta_{e m, m}=-0.8$, then $\left(1+\beta_{e m, m}\right)^{-1}=5$, indicating 
that an asset's overall market beta is about 5 times the market beta of its cash flows. This is because an increase in the market is associated with a decrease in expected future excess returns on the market, and hence a decrease in expected excess returns on any asset that has a positive beta with the market. This decrease in expected future excess returns leads to a capital gain on the asset today, increasing the asset's beta with the market.

All the beta components in (17) are betas with the overall market return. But it is possible to break the market return itself into components $\tilde{e}_{d m}, \bar{e}_{r}$, and $\tilde{e}_{e m}$, representing news about future market cash flows, real interest rates, and market excess returns. (This is the exercise undertaken in Campbell (1991) and Campbell and Ammer (1993).) Then the covariances of individual asset cash flows and real interest rates with the market can be broken down into covariances with market cash flow news, real interest rate news, and market excess return news. An asset whose cash flows have a high market beta (a high $\beta_{d i, m}$ ) need not be an asset whose cash flows have a high covariance with market cash flow news $\tilde{e}_{d m}$. A high-beta asset could instead be an asset whose cash flows covary negatively with real interest rate news $\tilde{e}_{r}$ or with news about future market excess returns $\tilde{e}_{e m}$.

Equation (17) also illustrates the conditions under which overall market betas $\beta_{i, m}$ equal cash flow market betas $\beta_{d i, m}$. This requires $\beta_{r, m}=0$ (real interest rates uncorrelated with the market return), and $\beta_{e m, m}=0$ (expected future excess market returns uncorrelated with the market return). Sufficient but not necessary conditions are that real interest rates and expected excess market returns are constant; in this case we have the stronger result $\beta_{i, m}=\beta_{d i, d m}$ and betas are determined by covariances of asset cash flow news with market cash flow news.

It is interesting to ask whether our empirical beta decomposition for industry and size portfolios conforms to the pattern predicted by the CAPM with constant conditional betas. Figure 1 (for industry portfolios) and Figure 2 (for size portfolios) show the theoretical relation derived in equation (17) as a solid line. The intercept and slope are VAR estimates of $\beta_{r, m}$ and $\left(1+\beta_{e m, m}\right)^{-1}$ respectively. Our unrestricted estimates of $\beta_{d i, m}$ and $\beta_{i, m}$ for each portfolio are shown as scatterpoints in the figure, and an unrestricted OLS regression through these points is shown as a dashed line. It is apparent from Figures 1 and 2 that the CAPM does not fit these results. The CAPM predicts that the scatterpoints should lie along a line with an intercept close to zero and a slope of about 5 . Instead, in both figures the points lie along a line with an 
intercept close to one and a slope between 0.2 and 0.5 . There is considerable variation in $\beta_{d i, m}$ but the $\beta_{e i, m}$ components dampen this variation rather than amplifying it as required by the CAPM. This result can also be seen directly in Tables 1 and 4 , where assets with large cash flow betas are not necessarily those with large excess return betas (in absolute value). As one would expect from this informal visual presentation, the restrictions imposed by the CAPM on the econometric model are statistically rejected. We report tests of the restrictions in Table 6 below.

\subsection{Multi-Factor Models}

The above analysis generalizes straightforwardly to a multi-factor asset pricing model. A $K$-factor model for returns with constant conditional betas implies that the unexpected excess return on asset $i$ satisfies

$$
\tilde{e}_{i, t+1}=\sum_{k=1}^{K} \beta_{i, k} \tilde{f}_{k, t+1}+v_{i, t+1}
$$

The unexpected excess return is written as the sum of $K$ factor innovations $\tilde{f}_{k, t+1}$ times their factor loadings $\beta_{i, k}$ plus an idiosyncratic shock $v_{i, t+1}$.

Given the factor structure (18), no-arbitrage or equilibrium arguments can be used to derive the standard restriction on expected returns:

$$
E_{t} e_{i, t+1}=\sum_{k=1}^{K} \beta_{i, k} \lambda_{k, t}
$$

where $\lambda_{k, t}$ is the conditional risk premium on the $k^{\prime}$ th factor, known at time $t$ and applying to time $t+1$. The news about future excess return on asset $i$ can now be rewritten as 


$$
\begin{aligned}
\tilde{e}_{e i} & =\sum_{k=1}^{K} \beta_{i, k}\left(E_{t+1}-E_{t}\right) \sum_{j=1}^{\infty} \rho^{j} \lambda_{k, t+j} \\
& =\sum_{k=1}^{K} \beta_{i, k} \tilde{\eta}_{\lambda k}=\beta_{i}^{\prime} \tilde{\eta}_{\lambda}
\end{aligned}
$$

where $\tilde{\eta}_{\lambda k}$ is news about future risk prices on the $k^{\prime}$ th factor, and $\beta_{i}$ and $\tilde{\eta}_{\lambda}$ are column vectors containing $\beta_{i, k}$ and $\tilde{\eta}_{\lambda k}, k=1 \ldots K$, respectively. Substituting (20) into (8), we find that

$$
\beta_{i, k}=\beta_{d i, k}-\beta_{r, k}-\frac{\operatorname{Cov}\left(\beta_{i}^{\prime} \tilde{\eta}_{\lambda}, \tilde{f}_{k}\right)}{\operatorname{Var}\left(\tilde{f}_{k}\right)}
$$

This implies that the vector $\beta_{i}$ obeys

$$
\beta_{i}=(I+\Lambda)^{-1}\left(\beta_{d i}-\beta_{r}\right)
$$

where $\Lambda \equiv \operatorname{Var}(\tilde{f})^{-1} \operatorname{Cov}\left(\tilde{f}, \tilde{\eta}_{\lambda}^{\prime}\right)$, and $\beta_{d i}$ and $\beta_{r}$ are column vectors containing $\beta_{d i, k}$ and $\beta_{r, k}, k=1 \ldots K$, respectively.

Equation (22) is the multi-factor generalization of equation (17). It is complicated by the fact that the risk price of one factor can covary with other factors; this is what requires us to solve for the whole vector of betas simultaneously. If we rule this out, imposing that $\operatorname{Cov}\left(\tilde{\eta}_{\lambda k}, \tilde{f}_{l}\right)=0$ for $k \neq l$, then we get the simpler relation

$$
\begin{aligned}
\beta_{i, k} & =\left[1+\frac{\operatorname{Cov}\left(\tilde{\eta}_{\lambda k}, \tilde{f}_{k}\right)}{\operatorname{Var}\left(\tilde{f}_{k}\right)}\right]^{-1}\left(\beta_{d i, k}-\beta_{r, k}\right) \\
& =\left(1+\beta_{\lambda k, k}\right)^{-1}\left(\beta_{d i, k}-\beta_{r, k}\right),
\end{aligned}
$$

which is directly analogous to (17). 


\subsection{Beta Decomposition with Multi-Factor Restrictions}

Multi-factor models can be used in empirical work to reduce the number of parameters that must be estimated. The general VAR methodology described in Section 1.3 places very little structure on expected asset returns. The expected return on each asset depends on the same vector of state variables, but in an unrestricted way. This means that the number of parameters increases very rapidly with the number of assets, which can create econometric difficulties. If we are willing to apply the restriction (19) implied by a $K$-factor asset pricing model, however, we can put extra structure on the problem. (19) says that expected excess returns on any asset are given by the sum of $K$ factor loadings $\beta_{i, k}$ times $K$ prices of factor risk $\lambda_{k t}$. Under our assumption that the information set at time $t$ is the vector $x_{t}$, we can write $\lambda_{k t}$ as

$$
\lambda_{k t}=\sum_{l=1}^{L} \theta_{k l} x_{l t} .
$$

Substituting equation (24) into equation (19), we find that the coefficients $a_{i l}$ of the vector $a_{i}$ in equation (9) are restricted as follows:

$$
a_{i l}=\sum_{k=1}^{K} \beta_{i, k} \theta_{k l} .
$$

Equation (25) is a latent variable model with $K$ latent variables, as introduced to the asset pricing literature by Gibbons and Ferson (1985) and Hansen and Hodrick (1983). Whenever there are more assets than factors, the restrictions in (25) greatly reduce the number of free parameters in the model. This is true even when we treat the factors and factor loadings as unobservable; if the factors are assumed to be innovations in the economic state variables, then the $\beta_{i k}$ can be estimated from the contemporaneous covariances of asset returns and state variables, leaving only the $\theta_{k l}$ to be estimated from the regression coefficients for expected returns.

The decomposition of systematic risk into cash flow risk and discount rate risk is quite robust to whether we impose asset pricing restrictions (25) and to the number of systematic factors in the economy. We support this claim in Table 6, which presents 
point estimates of the sensitivities of cash flow news on the market portfolio to macroeconomic state variables, using four different estimation procedures. Panel $\mathbf{A}$ imposes no asset pricing restrictions in estimating equations (9) and (10). Panel $B$ estimates the model imposing the CAPM, that is equation (25) with the market return as a single observable factor. Panel $\mathrm{C}$ imposes (25) assuming that there is a single unobserved factor. Panel D imposes (25) assuming that there are five observable factors which are the five variables in the VAR system. Panel $\mathrm{E}$ reports tests of the overidentifying restrictions implied by these asset pricing models. The CAPM is rejected, but there is only weak evidence against the other sets of restrictions. ${ }^{6}$

As one would expect from this, the market portfolio's cash flow betas in Table 6 are affected most strongly by imposing the CAPM, but are barely altered by imposing the other asset pricing models. Results for other portfolios (not reported in the table) follow a similar pattern; CAPM restrictions alter the results by forcing the points shown in Figures 1 and 2 to lie along a line with a slope of 4 or 5 , but other restrictions have little effect. The main exception is that the pattern of results across size portfolios becomes smoother when a single-unobserved-factor model is imposed.

Table 6 also reports the sensitivity of our results to two other changes in specification. Dropping the last three months of our sample, to avoid the volatile period following the stock market crash of October 1987, has little effect on the estimated market cash flow betas. The beta decomposition appears to be somewhat more sensitive to the choice of VAR lag length. When we increase the lag length to 2 in Table 6 we estimate a slightly higher cash flow sensitivity to real interest rates and inflation, but otherwise get results similar to the single-lag VAR cases.

Although our point estimates are insensitive to specification, as shown in Table 6, we find that the standard errors of our estimates are quite sensitive to different sets of restrictions and different VAR lag lengths. This is to be expected, because as we relax restrictions and increase lag length we greatly increase the number of parameters to be estimated. 


\section{Conclusions}

In this paper we have used a dynamic accounting framework to break unexpected asset returns into components associated with changing expectations of future cash flows, real interest rates, and expected future excess returns. We have then calculated the betas of the individual components with the aggregate market and with various economic state variables. This approach has produced several intriguing results.

First, expected excess return betas with the aggregate market are typically much larger in absolute value than cash flow betas with the market. Variation in expected excess returns on individual portfolios acts to increase the covariation of these portfolios with the overall stock market.

Second, cash flow betas, future real interest rate betas and expected excess return betas often have offsetting effects on the overall betas of assets with economic state variables. When inflation increases or the ex post real interest rate declines, the negative effects on stock prices of reduced cash flow and increased expected excess returns outweigh the positive effect on stock prices of declining future real interest rates. When industrial production increases, the negative effect of increased expected excess returns largely offsets the positive effect of increased expected cash flow.

Third, there is no strong cross-sectional correlation between assets' cash flow betas and their expected excess return betas. Cash flow betas with the market, for example, vary inversely with firm size but expected excess return betas with the market do not vary strongly with firm size. The CAPM predicts that assets whose cash flows covary strongly with the market should also have expected excess returns that covary strongly with the market, but we find no evidence of this effect in the data.

There are of course some caveats that should be kept in mind when interpreting these results. Our approach depends on the use of a loglinear approximation to the true present value relation. It also depends on the correct specification of the information set used by investors to forecast future returns. We have treated cash flows as a residual, and so a misspecification of the information set could affect our estimates of both cash flow betas and expected excess return betas. An Appendix to this paper, available from the authors on request, shows that the loglinear system used here has only small approximation error which should not affect our results in any important way.

This paper has also made a methodological contribution. We have integrated several approaches which are often used separately in empirical finance: estimation of 
a contemporaneous multi-factor model, analysis of the present value relationship, and analysis of asset expected returns in relation to the dynamic behavior of economic state variables. We believe that the best future research in asset pricing will treat these as elements of a single system.

The approach of this paper can be extended in several ways. We have used only aggregate variables to forecast returns on stock portfolios; it would be interesting to see whether portfolio-specific forecasting variables would affect the results. We have explored the restrictions imposed by asset pricing models only in the most preliminary way, and there is much more research that can be done in this area. It would also be interesting to use the methods of this paper to study time-varying conditional betas. Finally, our approach can be applied to other types of common factors, such as the nominal interest rate movements studied by Campbell and Ammer (1993), and to other assets, such as the national stock indexes studied by Ammer and Mei (1992). 


\section{Notes}

*. We wish to thank Wayne Ferson, Robert Stambaugh (the editor), Chester Spatt (the executive editor), and an anonymous referee for helpful comments. Campbell acknowledges financial support from the National Science Foundation and the Sloan Foundation. Mei has received financial support from the New York University summer research grant.

1. Our paper builds on the vast literature showing that expected asset returns change through time, for example Campbell (1987), Fama and French (1988a,b, 1989), Keim and Stambaugh (1986), Lo and MacKinlay (1988), and Poterba and Summers (1988). There has also been some cross-sectional work relating betas to observable characteristics of firms, for example Rosenberg and Marathe (1975) and Chan and Chen (1991), but this work does not make the distinction emphasized here between different sources of news.

2. We are grateful to Wayne Ferson for providing us with these portfolio returns. Ferson and Harvey (1991) give more detail on the construction of the portfolios.

3. These results are sensitive to the way in which inflation is measured. Campbell and Ammer (1993) study not contemporaneous inflation, but news about long-run future inflation. They find that if anything such news has a positive effect on the stock market.

4. Campbell (1987), Ferson (1990), Ferson and Harvey (1991), Shanken (1990), and others test for constant conditional betas in multi-factor asset pricing models. The hypothesis that conditional betas are constant is easy to reject in models with a small number of factors, but much harder to reject when more factors are allowed. Ferson and Harvey (1991) argue that for the portfolios studied here, variation in betas is small relative to variation in factor risk prices.

5. Recall that our application of the Campbell-Shiller linearization imposes the same $\rho$ for all assets, effectively assuming that all assets are equally sensitive to a given change in the expected time path of real interest rates.

6. All these tests take the variance-covariance matrix of VAR innovations as being known. We have also experimented with using a larger number of iterations in the 
GMM estimation procedure. As pointed out by Ferson and Foerster (1991), this can improve the finite-sample properties of latent variable model estimates. We find that our results are quite robust to the number of iterations, presumably because our sample size is large compared to the number of asset portfolios we study. Ferson and Foerster (1991) also suggest using a finite-sample correction for standard errors in GMM models. In our application this correction would increase reported standard errors for industry portfolios by $17 \%$ and for size portfolios by $13 \%$. 


\section{References}

Ammer, John, and Jianping Mei, 1992, "Measuring International Economic Linkages with Stock Market Data," unpublished paper, Federal Reserve Board and New York University.

Campbell, John Y., 1987, "Stock Returns and the Term Structure," Journal of Financial Economics, 18, 373-399.

Campbell, John Y., 1991, "A Variance Decomposition for Stock Returns," the H.G. Johnson Lecture to the Royal Economic Society, Economic Journal, 101, 157-179.

Campbell, John Y., and John Ammer, 1993, "What Moves the Stock and Bond Markets? A Variance Decomposition for Long-Term Asset Returns," forthcoming Journal of Finance.

Campbell, John Y., and Robert J. Shiller, 1988, "The Dividend-Price Ratio and Expectations of Future Dividends and Discount Factors," Review of Financial Studies, 1, 195-228.

Chan, K.C., and Nai-fu Chen, 1991, "Structural and Return Characteristics of Small and Large Firms," Journal of Finance, 46, 1467-1484.

Chen, Nai-fu, 1991, "Financial Investment Opportunities and the Macroeconomy," Journal of Finance, 46, 529-554.

Chen, Nai-fu, Richard Roll, and Stephen A. Ross, 1986, "Economic Forces and the Stock Market," Journal of Business, 59, 383-403.

Cutler, David M., James M. Poterba, and Lawrence H. Summers, 1989, "What Moves Stock Prices?," Journal of Portfolio Management, 15, 4-12.

Fama, Eugene F., 1990, "Stock Returns, Expected Returns, and Real Activity," Journal of Finance, 45, 1089-1108.

Fama, Eugene F., and Kenneth R. French, 1988a, "Permanent and Temporary Components of Stock Prices," Journal of Political Economy, 96, 246-273. 
Fama, Eugene F., and Kenneth R. French, 1988b, "Dividend Yields and Expected Stock Returns," Journal of Financial Economics, 22, 3-25.

Fama, Eugene F., and Kenneth R. French, 1989, "Business Conditions and Expected Returns on Stocks and Bonds," Journal of Financial Economics, 25, 23-49.

Fama, Eugene F., and G. William Schwert, 1977, “Asset Returns and Inflation," Journal of Financial Economics, 5, 115-146.

Ferson, Wayne E., 1990, "Are the Latent Variables in Time-Varying Expected Returns Compensation for Consumption Risk?," Journal of Finance, 45, 397-429.

Ferson, Wayne E., and Stephen R. Foerster, 1991, "Finite Sample Properties of the Generalized Method of Moments in Tests of Conditional Asset Pricing Models," unpublished paper, University of Chicago.

Ferson, Wayne E., and Campbell R. Harvey, 1991, "The Variation of Economic Risk Premiums," Journal of Political Economy, 99, 385-415.

Gibbons, Michael R., and Wayne E. Ferson, 1985, "Tests of Asset Pricing Models with Changing Expectations and an Unobservable Market Portfolio," Journal of Financial Economics, 14, 217-236.

Hansen, Lars Peter, 1982, "Large Sample Properties of Generalized Method of Moments Estimators," Econometrica, 50, 1029-1054.

Hansen, Lars Peter, and Robert J. Hodrick, 1983, "Risk Averse Speculation in the Forward Foreign Exchange Market, An Econometric Analysis of Linear Models," in Jacob A. Frenkel ed., Exchange Rates and International Economics, University of Chicago Press, Chicago, Illinois.

Hodrick, Robert J., 1992, "Dividend Yields and Expected Stock Returns, Alternative Procedures for Inference and Measurement," Review of Financial Studies, 5, 357386.

Kandel, Shmuel, and Robert F. Stambaugh, 1988, "Modelling Expected Stock Returns for Short and Long Horizons," Working Paper 42-88, Rodney L. White Center for Financial Research, Wharton School, University of Pennsylvania. 
Keim, Donald B., and Robert F. Stambaugh, 1986, "Predicting Returns in the Stock and Bond Markets," Journal of Financial Economics, 17, 357-390.

Lintner, John, 1965, "The Valuation of Risk Assets and the Selection of Risky Invest-

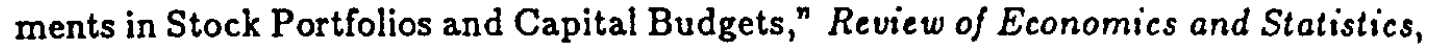
47, 13-37.

Lo, Andrew W., and A. Craig MacKinlay, 1988, "Stock Market Prices Do Not Follow Random Walks, Evidence from a Simple Specification Test," Review of Financial Studies, 1, 41-66.

Merton, Robert C., 1973, "An Intertemporal Capital Asset Pricing Model," Econometrica, $41,867-887$.

Poterba, James M., and Lawrence H. Summers, 1988, "Mean Reversion in Stock Prices, Evidence and Implications," Journal of Financial Economics, 22, 27-59.

Rosenberg, Barr, and V. Marathe, 1975, "The Prediction of Investment Risk, Systematic and Residual Risk," Proceedings of the Seminar on the Analysis of Security Prices, Center for Research in Security Prices, University of Chicago, 85-226.

Ross, Stephen A., 1976, "The Arbitrage Theory of Capital Asset Pricing," Journal of Economic Theory, 13, 341-360.

Shanken, Jay, 1990, "Intertemporal Asset Pricing, An Empirical Investigation," Journal of Econometrics, 45, 99-120.

Sharpe, William F., 1964, "Capital Asset Prices, A Theory of Market Equilibrium Under Conditions of Risk," Journal of Finance, 19, 425-442.

Sims, Christopher A., 1980, "Vector Autoregressions and Reality," Econometrica, 48, $1-48$.

Stambaugh, Robert F., 1990, "Factors in Expected Returns," unpublished paper, Wharton School, University of Pennsylvania.

White, Halbert, 1984, Asymptotic Theory for Econometricians, Academic Press, Orlando, Florida. 
</ref_section> 
Table 1

Decomposition of Market Betas for Industry Portfolios

\begin{tabular}{|c|c|c|c|c|c|}
\hline & $\beta_{1, m}$ & $\beta_{\mathrm{di}, \mathrm{m}}$ & $\beta_{\text {ei,m }}$ & $\beta_{\text {di, dm }}$ & $\mathrm{R}^{2}$ \\
\hline Petroleum & $\begin{array}{c}0.949 \\
(0.042)\end{array}$ & $\begin{array}{c}0.171 \\
(0.207)\end{array}$ & $\begin{array}{l}-0.789 \\
(0.207)\end{array}$ & $\begin{array}{c}0.779 \\
(0.410)\end{array}$ & $\begin{array}{l}0.028 \\
(0.855)\end{array}$ \\
\hline $\begin{array}{l}\text { Finance/ } \\
\text { Real Estate }\end{array}$ & $\begin{array}{c}0.996 \\
(0.023)\end{array}$ & $\begin{array}{c}0.029 \\
(0.163)\end{array}$ & $\begin{array}{l}-0.978 \\
(0.158)\end{array}$ & $\begin{array}{c}0.690 \\
(0.224)\end{array}$ & $\begin{array}{l}0.047 \\
(0.986)\end{array}$ \\
\hline $\begin{array}{l}\text { Consumer } \\
\text { Durables }\end{array}$ & $\begin{array}{c}1.122 \\
(0.033)\end{array}$ & $\begin{array}{c}0.060 \\
(0.204)\end{array}$ & $\begin{array}{l}-1.073 \\
(0.201)\end{array}$ & $\begin{array}{c}1.219 \\
(0.274)\end{array}$ & $\begin{array}{l}0.064 \\
(1.315)\end{array}$ \\
\hline Basic Industries & $\begin{array}{c}1.078 \\
(0.019)\end{array}$ & $\begin{array}{c}0.381 \\
(0.150)\end{array}$ & $\begin{array}{l}-0.708 \\
(0.148)\end{array}$ & $\begin{array}{c}1.197 \\
(0.214)\end{array}$ & $\begin{array}{l}0.033 \\
(0.864)\end{array}$ \\
\hline Food/Tobacco & $\begin{array}{c}0.853 \\
(0.029)\end{array}$ & $\begin{array}{c}0.235 \\
(0.151)\end{array}$ & $\begin{array}{l}-0.630 \\
(0.137)\end{array}$ & $\begin{array}{c}0.684 \\
(0.377)\end{array}$ & $\begin{array}{c}0.037 \\
(0.784)\end{array}$ \\
\hline Construction & $\begin{array}{c}1.171 \\
(0.043)\end{array}$ & $\begin{array}{c}0.098 \\
(0.212)\end{array}$ & $\begin{array}{l}-1.084 \\
(0.211)\end{array}$ & $\begin{array}{c}1.081 \\
(0.269)\end{array}$ & $\begin{array}{c}0.054 \\
(1.293)\end{array}$ \\
\hline Capital Goods & $\begin{array}{c}1.063 \\
(0.024)\end{array}$ & $\begin{array}{c}0.372 \\
(0.222)\end{array}$ & $\begin{array}{l}-0.703 \\
(0.217)\end{array}$ & $\begin{array}{c}1.689 \\
(0.387)\end{array}$ & $\begin{array}{c}0.066 \\
(1.282)\end{array}$ \\
\hline Transportation & $\begin{array}{c}1.180 \\
(0.037)\end{array}$ & $\begin{array}{c}0.273 \\
(0.210)\end{array}$ & $\begin{array}{l}-0.918 \\
(0.203)\end{array}$ & $\begin{array}{c}1.092 \\
(0.270)\end{array}$ & $\begin{array}{l}0.037 \\
(1.119)\end{array}$ \\
\hline Uituities & $\begin{array}{c}0.619 \\
(0.030)\end{array}$ & $\begin{array}{l}-0 \hat{.125} \\
(0.161)\end{array}$ & $\begin{array}{l}-0.756 \\
(0.155)\end{array}$ & $\begin{array}{c}0.407 \\
(0.304)\end{array}$ & $\begin{array}{l}0.050 \\
(0.750)\end{array}$ \\
\hline Textile/Trade & $\begin{array}{c}1.043 \\
(0.053)\end{array}$ & $\begin{array}{c}0.359 \\
(0.215)\end{array}$ & $\begin{array}{l}-0.696 \\
(0.211)\end{array}$ & $\begin{array}{c}1.222 \\
(0.400)\end{array}$ & $\begin{array}{l}0.048 \\
(1.153)\end{array}$ \\
\hline Services & $\begin{array}{c}1.164 \\
(0.041)\end{array}$ & $\begin{array}{l}-0.151 \\
(0.300)\end{array}$ & $\begin{array}{l}-1.327 \\
(0.299)\end{array}$ & $\begin{array}{c}0.733 \\
(0.546)\end{array}$ & $\begin{array}{l}0.056 \\
(1.393)\end{array}$ \\
\hline Leisure & $\begin{array}{c}1.209 \\
(0.048)\end{array}$ & $\begin{array}{c}0.178 \\
(0.257)\end{array}$ & $\begin{array}{l}-1.042 \\
(0.256)\end{array}$ & $\begin{array}{c}1.210 \\
(0.449)\end{array}$ & $\begin{array}{l}0.063 \\
(1.505)\end{array}$ \\
\hline
\end{tabular}

Note: $\beta_{\mathrm{i}, \mathrm{m}}$ is the return sensitivity to the market return. $\beta_{\mathrm{d}, \mathrm{m}}$ is the sensitivity of cash flow news to the market return. $\beta_{\text {el, } m}$ is the sensitivity of excess return news to the market return. $\beta_{d \mu, d m}$ is the sensitivity of cash flow news to the market's cash flow news. $\beta_{r, m}$, which is the sensitivity of real interest rate news to the market return, is equal to 0.012 . The number in parenthesis below $R^{2}$ gives the standard deviation of conditional expected excess returns. We use the value-weighted NYSE index for the market portfolio. The sample covers the time period from 1952:1 to 1987:12. 
Table 2

Decomposition of Observable Factor Betas for Industry Portfolios

\begin{tabular}{|c|c|c|c|c|c|c|c|c|}
\hline & \multicolumn{4}{|c|}{ Cash Flow Components } & \multicolumn{4}{|c|}{ Excess Return Components } \\
\hline & mate & $\mathrm{D} / \mathrm{P}_{\mathrm{m}}$ & infn & IPG & rrate & $\mathrm{D} / \mathrm{P}_{\mathrm{m}}$ & infn & IPG \\
\hline Market & $\begin{array}{c}0.202 \\
(0.070)\end{array}$ & $\begin{array}{l}-0.015 \\
(0.030)\end{array}$ & $\begin{array}{l}-0.262 \\
(0.093)\end{array}$ & $\begin{array}{c}0.014 \\
(0.012)\end{array}$ & $\begin{array}{l}-0.030 \\
(0.093)\end{array}$ & $\begin{array}{c}0.201 \\
(0.029)\end{array}$ & $\begin{array}{c}0.011 \\
(0.119)\end{array}$ & $\begin{array}{c}0.010 \\
(0.019)\end{array}$ \\
\hline Petroleum & $\begin{array}{l}-0.071 \\
(0.146)\end{array}$ & $\begin{array}{l}-0.023 \\
(0.050)\end{array}$ & $\begin{array}{l}-0.057 \\
(0.229)\end{array}$ & $\begin{array}{c}0.006 \\
(0.031)\end{array}$ & $\begin{array}{l}-0.143 \\
(0.152)\end{array}$ & $\begin{array}{c}0.188 \\
(0.051)\end{array}$ & $\begin{array}{c}0.047 \\
(0.240)\end{array}$ & $\begin{array}{c}0.006 \\
(0.033)\end{array}$ \\
\hline $\begin{array}{l}\text { Finance/ } \\
\text { Real Estate }\end{array}$ & $\begin{array}{c}0.113 \\
(0.103)\end{array}$ & $\begin{array}{c}0.020 \\
(0.038)\end{array}$ & $\begin{array}{l}-0.107 \\
(0.134)\end{array}$ & $\begin{array}{c}-0.002 \\
(0.017)\end{array}$ & $\begin{array}{l}-0.128 \\
(0.126)\end{array}$ & $\begin{array}{c}0.236 \\
(0.037)\end{array}$ & $\begin{array}{c}0.154 \\
(0.156)\end{array}$ & $\begin{array}{c}0.007 \\
(0.022)\end{array}$ \\
\hline $\begin{array}{l}\text { Consumer } \\
\text { Durables }\end{array}$ & $\begin{array}{c}0.234 \\
(0.123)\end{array}$ & $\begin{array}{c}0.020 \\
(0.048)\end{array}$ & $\begin{array}{l}-0.312 \\
(0.171)\end{array}$ & $\begin{array}{c}0.020 \\
(0.024)\end{array}$ & $\begin{array}{l}-0.038 \\
(0.147)\end{array}$ & $\begin{array}{c}0.260 \\
(0.049)\end{array}$ & $\begin{array}{l}0.003 \\
(0.196)\end{array}$ & $\begin{array}{c}0.020 \\
(0.030)\end{array}$ \\
\hline $\begin{array}{l}\text { Basic } \\
\text { Industries }\end{array}$ & $\begin{array}{c}0.228 \\
(0.105)\end{array}$ & $\begin{array}{l}-0.063 \\
(0.035)\end{array}$ & $\begin{array}{l}-0.336 \\
(0.149)\end{array}$ & $\begin{array}{l}0.013 \\
(0.018)\end{array}$ & $\begin{array}{l}-0.022 \\
(0.110)\end{array}$ & $\begin{array}{c}0.171 \\
(0.036)\end{array}$ & $\begin{array}{l}-0.035 \\
(0.163)\end{array}$ & $\begin{array}{c}0.046 \\
(0.025)\end{array}$ \\
\hline $\begin{array}{l}\text { Food } \\
\text { Tobacco }\end{array}$ & $\begin{array}{c}0.358 \\
(0.100)\end{array}$ & $\begin{array}{l}-0.030 \\
(0.035)\end{array}$ & $\begin{array}{l}-0.288 \\
(0.146)\end{array}$ & $\begin{array}{c}0.012 \\
(0.020)\end{array}$ & $\begin{array}{l}0.058 \\
(0.099)\end{array}$ & $\begin{array}{c}0.154 \\
(0.033)\end{array}$ & $\begin{array}{l}0.050 \\
(0.133)\end{array}$ & $\begin{array}{c}0.006 \\
(0.018)\end{array}$ \\
\hline $\begin{array}{l}\text { Constru- } \\
\text { ction }\end{array}$ & $\begin{array}{c}0.086 \\
(0.128)\end{array}$ & $\begin{array}{c}0.013 \\
(0.050)\end{array}$ & $\begin{array}{l}-0.127 \\
(0.162)\end{array}$ & $\begin{array}{c}0.026 \\
(0.025)\end{array}$ & $\begin{array}{l}-0.148 \\
(0.147)\end{array}$ & $\begin{array}{c}0.265 \\
(0.051)\end{array}$ & $\begin{array}{l}0.167 \\
(0.186)\end{array}$ & $\begin{array}{c}0.013 \\
(0.030)\end{array}$ \\
\hline $\begin{array}{l}\text { Capital } \\
\text { Goods }\end{array}$ & $\begin{array}{c}0.383 \\
(0.156)\end{array}$ & $\begin{array}{c}-0.059 \\
(0.053)\end{array}$ & $\begin{array}{l}-0.603 \\
(0.228)\end{array}$ & $\begin{array}{c}0.040 \\
(0.030)\end{array}$ & $\begin{array}{l}0.167 \\
(0.158)\end{array}$ & $\begin{array}{c}0.169 \\
(0.053)\end{array}$ & $\begin{array}{l}-0.332 \\
(2.239 ;\end{array}$ & $\begin{array}{c}0.029 \\
(2.033)\end{array}$ \\
\hline $\begin{array}{l}\text { Transpor- } \\
\text { tation }\end{array}$ & $\begin{array}{c}0.212 \\
(0.122)\end{array}$ & $\begin{array}{l}-0.033 \\
(0.050)\end{array}$ & $\begin{array}{l}-0.263 \\
(0.175)\end{array}$ & $\begin{array}{c}0.011 \\
(0.026)\end{array}$ & $\begin{array}{l}-0.062 \\
(0.140)\end{array}$ & $\begin{array}{c}0.224 \\
(0.049)\end{array}$ & $\begin{array}{c}0.092 \\
(0.192)\end{array}$ & $\begin{array}{c}0.018 \\
(0.027)\end{array}$ \\
\hline Utilities & $\begin{array}{c}0.213 \\
(0.106)\end{array}$ & $\begin{array}{c}0.047 \\
(0.038)\end{array}$ & $\begin{array}{l}-0.166 \\
(0.154)\end{array}$ & $\begin{array}{c}0.002 \\
(0.020)\end{array}$ & $\begin{array}{l}-0.057 \\
(0.088)\end{array}$ & $\begin{array}{c}0.182 \\
(0.037)\end{array}$ & $\begin{array}{l}0.126 \\
(0.156)\end{array}$ & $\begin{array}{c}-0.001 \\
(0.020)\end{array}$ \\
\hline $\begin{array}{l}\text { Textile/ } \\
\text { Trade }\end{array}$ & $\begin{array}{c}0.483 \\
(0.140)\end{array}$ & $\begin{array}{l}-0.049 \\
(0.051)\end{array}$ & $\begin{array}{l}-0.462 \\
(0.192)\end{array}$ & $\begin{array}{c}0.045 \\
(0.026)\end{array}$ & $\begin{array}{c}0.156 \\
(0.137)\end{array}$ & $\begin{array}{c}0.170 \\
(0.051)\end{array}$ & $\begin{array}{l}-0.092 \\
(0.185)\end{array}$ & $\begin{array}{c}0.040 \\
(0.025)\end{array}$ \\
\hline Services & $\begin{array}{c}0.118 \\
(0.171)\end{array}$ & $\begin{array}{c}0.075 \\
(0.071)\end{array}$ & $\begin{array}{l}-0.032 \\
(0.227)\end{array}$ & $\begin{array}{c}0.008 \\
(0.032)\end{array}$ & $\begin{array}{l}-0.233 \\
(0.195)\end{array}$ & $\begin{array}{c}0.324 \\
(0.071)\end{array}$ & $\begin{array}{l}0.363 \\
(0.241)\end{array}$ & $\begin{array}{c}0.008 \\
(0.036)\end{array}$ \\
\hline Leisure & $\begin{array}{c}0.359 \\
(0.153)\end{array}$ & $\begin{array}{c}0.002 \\
(0.061)\end{array}$ & $\begin{array}{l}-0.315 \\
(0.202)\end{array}$ & $\begin{array}{c}0.012 \\
(0.029)\end{array}$ & $\begin{array}{l}-0.015 \\
(0.164)\end{array}$ & $\begin{array}{c}0.258 \\
(0.062)\end{array}$ & $\begin{array}{l}0.113 \\
(0.203)\end{array}$ & $\begin{array}{c}0.007 \\
(0.028)\end{array}$ \\
\hline$\beta_{r, k}$ & $\begin{array}{c}0.154 \\
(0.021)\end{array}$ & $\begin{array}{c}-0.002 \\
(0.007)\end{array}$ & $\begin{array}{l}-0.126 \\
(0.033)\end{array}$ & $\begin{array}{l}-0.001 \\
(0.004)\end{array}$ & & & & \\
\hline
\end{tabular}

Note: The unit for each variable is percentage point per annum for rrate (real interest rate), basis point for $D / P_{m}$, percentage point per annum for infn (inflation), percentage point per annum for IPG (industrial production growth, seasonally adjusted). The sample covers the time period from 1952:1 to 1987:12. 
Table 3

Decomposition of Market Betas for Size Portfolios

\begin{tabular}{|c|c|c|c|c|c|}
\hline & $\beta_{i, m}$ & $\beta_{\mathrm{d}, \mathrm{m}}$ & $\beta_{e i, m}$ & $\beta_{\mathrm{di}, \mathrm{dm}}$ & $R^{2}$ \\
\hline Decile 1 & $\begin{array}{c}1.170 \\
(0.079)\end{array}$ & $\begin{array}{c}0.467 \\
(0.278)\end{array}$ & $\begin{array}{l}-0.715 \\
(0.285)\end{array}$ & $\begin{array}{c}1.152 \\
(0.523)\end{array}$ & $\begin{array}{c}0.048 \\
(1.412)\end{array}$ \\
\hline Decile 2 & $\begin{array}{c}1.153 \\
(0.062)\end{array}$ & $\begin{array}{c}0.267 \\
(0.239)\end{array}$ & $\begin{array}{l}-0.898 \\
(0.241)\end{array}$ & $\begin{array}{c}0.962 \\
(0.475)\end{array}$ & $\begin{array}{l}0.050 \\
(1.313)\end{array}$ \\
\hline Decile 3 & $\begin{array}{c}1.156 \\
(0.058)\end{array}$ & $\begin{array}{c}0.256 \\
(0.217)\end{array}$ & $\begin{array}{l}-0.912 \\
(0.217)\end{array}$ & $\begin{array}{c}1.037 \\
(0.406)\end{array}$ & $\begin{array}{c}0.054 \\
(1.288)\end{array}$ \\
\hline Decile 4 & $\begin{array}{c}1.128 \\
(0.045)\end{array}$ & $\begin{array}{c}0.198 \\
(0.197)\end{array}$ & $\begin{array}{l}-0.942 \\
(0.192)\end{array}$ & $\begin{array}{c}0.958 \\
(0.350)\end{array}$ & $\begin{array}{c}0.051 \\
(1.206)\end{array}$ \\
\hline Decile 5 & $\begin{array}{c}1.115 \\
(0.041)\end{array}$ & $\begin{array}{c}0.202 \\
(0.187)\end{array}$ & $\begin{array}{l}-0.925 \\
(0.184)\end{array}$ & $\begin{array}{c}0.987 \\
(0.315)\end{array}$ & $\begin{array}{l}0.052 \\
(1.185)\end{array}$ \\
\hline Decile 6 & $\begin{array}{c}1.101 \\
(0.038)\end{array}$ & $\begin{array}{c}0.150 \\
(0.179)\end{array}$ & $\begin{array}{l}-0.963 \\
(0.175)\end{array}$ & $\begin{array}{c}0.892 \\
(0.346)\end{array}$ & $\begin{array}{l}0.050 \\
(1.132)\end{array}$ \\
\hline Decile 7 & $\begin{array}{c}1.097 \\
(0.027)\end{array}$ & $\begin{array}{c}0.169 \\
(0.166)\end{array}$ & $\begin{array}{l}-0.940 \\
(0.162)\end{array}$ & $\begin{array}{c}0.993 \\
(0.216)\end{array}$ & $\begin{array}{c}0.051 \\
(1.096)\end{array}$ \\
\hline Decile 8 & $\begin{array}{c}1.076 \\
(0.022)\end{array}$ & $\begin{array}{c}0.156 \\
(0.147)\end{array}$ & $\begin{array}{l}-0.932 \\
(0.144)\end{array}$ & $\begin{array}{l}0.892 \\
(0.213)\end{array}$ & $\begin{array}{c}0.044 \\
(0.993)\end{array}$ \\
\hline Deciie 9 & $\begin{array}{c}i .025 \\
(0.014)\end{array}$ & $\begin{array}{c}0.094 \\
(0.145)\end{array}$ & $\begin{array}{l}-0.9+\div \\
(0.140)\end{array}$ & $\begin{array}{c}0.85 \div \\
(0.155)\end{array}$ & $\begin{array}{c}0.049 \\
(0.987)\end{array}$ \\
\hline Decile 10 & $\begin{array}{c}0.956 \\
(0.013)\end{array}$ & $\begin{array}{c}0.201 \\
(0.140)\end{array}$ & $\begin{array}{l}-0.767 \\
(0.135)\end{array}$ & $\begin{array}{c}1.058 \\
(0.127)\end{array}$ & $\begin{array}{c}0.053 \\
(0.944)\end{array}$ \\
\hline
\end{tabular}

Note: $\beta_{1, m}$ is the return sensitivity to the market return. $\beta_{d 1, m}$ is the sensitivity of cash flow news to the market return. $\beta_{\text {et, } m}$ is the sensitivity of excess return news to the market return. $\beta_{\mathrm{dl}, \mathrm{dm}}$ is the sensitivity of cash flow news to the market's cash flow news. $\beta_{r, m}$, which is the sensitivity of real interest rate news to the market return, is equal to 0.012 . The number in parenthesis below $R^{2}$ gives the standard deviation of conditional expected excess returns. Decile 1 is composed of small stocks from the first decile of size-sorted portfolios and Decile 10 is composed of large stocks from the last decile of size-sorted portfolios. We use the value-weighted NYSE index for the market portfolio. The sample covers the time period from 1952:1 to 1987:12. 
Table 4

Decomposition of Observable Factor Betas for Size Portfolios

\begin{tabular}{|c|c|c|c|c|c|c|c|c|}
\hline & \multicolumn{4}{|c|}{ Cash Flow Components } & \multicolumn{4}{|c|}{ Excess Return Components } \\
\hline & mate & $\mathrm{D} / \mathrm{P}_{\mathrm{m}}$ & infn & IPG & mate & $\mathrm{D} / \mathrm{P}_{\mathrm{m}}$ & infn & IPG \\
\hline Decile 1 & $\begin{array}{c}0.381 \\
(0.172)\end{array}$ & $\begin{array}{l}-0.074 \\
(0.067)\end{array}$ & $\begin{array}{l}-0.359 \\
(0.255)\end{array}$ & $\begin{array}{c}0.001 \\
(0.040)\end{array}$ & $\begin{array}{l}0.062 \\
(0.171)\end{array}$ & $\begin{array}{c}0.180 \\
(0.069)\end{array}$ & $\begin{array}{l}0.024 \\
(0.250)\end{array}$ & $\begin{array}{l}-0.001 \\
(0.037)\end{array}$ \\
\hline Decile 2 & $\begin{array}{c}0.315 \\
(0.148)\end{array}$ & $\begin{array}{l}-0.026 \\
(0.057)\end{array}$ & $\begin{array}{l}-0.258 \\
(0.214)\end{array}$ & $\begin{array}{c}-0.007 \\
(0.032)\end{array}$ & $\begin{array}{c}0.015 \\
(0.160)\end{array}$ & $\begin{array}{c}0.223 \\
(0.059)\end{array}$ & $\begin{array}{l}0.111 \\
(0.213)\end{array}$ & $\begin{array}{l}-0.007 \\
(0.032)\end{array}$ \\
\hline Decile 3 & $\begin{array}{c}0.301 \\
(0.138)\end{array}$ & $\begin{array}{l}-0.023 \\
(0.052)\end{array}$ & $\begin{array}{l}-0.266 \\
(0.197)\end{array}$ & $\begin{array}{c}0.006 \\
(0.028)\end{array}$ & $\begin{array}{l}0.012 \\
(0.153)\end{array}$ & $\begin{array}{c}0.226 \\
(0.053)\end{array}$ & $\begin{array}{l}0.088 \\
(0.201)\end{array}$ & $\begin{array}{c}0.004 \\
(0.028)\end{array}$ \\
\hline Decile 4 & $\begin{array}{c}0.228 \\
(0.126)\end{array}$ & $\begin{array}{l}-0.010 \\
(0.047)\end{array}$ & $\begin{array}{l}-0.196 \\
(0.171)\end{array}$ & $\begin{array}{l}-0.002 \\
(0.024)\end{array}$ & $\begin{array}{l}-0.074 \\
(0.144)\end{array}$ & $\begin{array}{c}0.233 \\
(0.047)\end{array}$ & $\begin{array}{l}0.169 \\
(0.178)\end{array}$ & $\begin{array}{c}-0.002 \\
(0.027)\end{array}$ \\
\hline Decile 5 & $\begin{array}{c}0.231 \\
(0.118)\end{array}$ & $\begin{array}{l}-0.011 \\
(0.045)\end{array}$ & $\begin{array}{l}-0.210 \\
(0.158)\end{array}$ & $\begin{array}{l}-0.003 \\
(0.023)\end{array}$ & $\begin{array}{l}-0.049 \\
(0.136)\end{array}$ & $\begin{array}{c}0.228 \\
(0.045)\end{array}$ & $\begin{array}{l}0.134 \\
(0.165)\end{array}$ & $\begin{array}{c}0.000 \\
(0.026)\end{array}$ \\
\hline Decile 6 & $\begin{array}{l}0.225 \\
(0.114)\end{array}$ & $\begin{array}{c}0.000 \\
(0.043)\end{array}$ & $\begin{array}{l}-0.181 \\
(0.153)\end{array}$ & $\begin{array}{c}0.005 \\
(0.020)\end{array}$ & $\begin{array}{l}-0.053 \\
(0.136)\end{array}$ & $\begin{array}{c}0.236 \\
(0.043)\end{array}$ & $\begin{array}{l}0.156 \\
(0.163)\end{array}$ & $\begin{array}{c}0.001 \\
(0.023)\end{array}$ \\
\hline Decile 7 & $\begin{array}{c}0.176 \\
(0.094)\end{array}$ & $\begin{array}{r}-0.006 \\
(0.040)\end{array}$ & $\begin{array}{l}-0.185 \\
(0.125)\end{array}$ & $\begin{array}{c}0.008 \\
(0.018)\end{array}$ & $\begin{array}{l}-0.091 \\
(0.123)\end{array}$ & $\begin{array}{c}0.230 \\
(0.039)\end{array}$ & $\begin{array}{l}0.138 \\
(0.146)\end{array}$ & $\begin{array}{c}0.008 \\
(0.023)\end{array}$ \\
\hline Decile 8 & $\begin{array}{c}0.166 \\
(0.088)\end{array}$ & $\begin{array}{l}-0.005 \\
(0.035)\end{array}$ & $\begin{array}{l}-0.164 \\
(0.119)\end{array}$ & $\begin{array}{c}0.016 \\
(0.016)\end{array}$ & $\begin{array}{l}-0.111 \\
(0.115)\end{array}$ & $\begin{array}{c}0.227 \\
(0.035)\end{array}$ & $\begin{array}{l}0.163 \\
(0.139)\end{array}$ & $\begin{array}{c}0.010 \\
(0.021)\end{array}$ \\
\hline Decile 9 & $\begin{array}{c}0.151 \\
(0.081)\end{array}$ & $\begin{array}{l}0.007 \\
(0.034)\end{array}$ & $\begin{array}{l}-0.169 \\
(0.103)\end{array}$ & $\begin{array}{c}0.006 \\
(0.014)\end{array}$ & $\begin{array}{c}-0.124 \\
(0.110)\end{array}$ & $\begin{array}{c}0.230 \\
(0.034)\end{array}$ & $\begin{array}{l}0.157 \\
(0.130)\end{array}$ & $\begin{array}{c}0.007 \\
(0.021)\end{array}$ \\
\hline Decile 10 & $\begin{array}{c}0.213 \\
(0.082)\end{array}$ & $\begin{array}{l}-0.023 \\
(0.033)\end{array}$ & $\begin{array}{l}-0.311 \\
(0.118)\end{array}$ & $\begin{array}{c}0.019 \\
(0.016)\end{array}$ & $\begin{array}{l}0.007 \\
(0.097)\end{array}$ & $\begin{array}{c}0.184 \\
(0.033)\end{array}$ & $\begin{array}{l}-0.073 \\
(0.140)\end{array}$ & $\begin{array}{c}0.013 \\
(0.021)\end{array}$ \\
\hline$\beta_{r, k}$ & $\begin{array}{c}0.154 \\
(0.021)\end{array}$ & $\begin{array}{l}-0.002 \\
(0.007)\end{array}$ & $\begin{array}{l}-0.126 \\
(0.033)\end{array}$ & $\begin{array}{c}-0.001 \\
(0.004)\end{array}$ & & & & \\
\hline
\end{tabular}

Note: The unit for each variable is percentage point per annum for rrate (real interest rate), basis point for $D / P_{m}$ percentage point per annum for infn (inflation), percentage point per annum for IPG (industrial production growth, seasonally adjusted). Decile 1 is composed of small stocks from the first decile of size-sorted portfolios and Decile 10 is composed of large stocks from the last decile of size-sorted portfolios. We use the value-weighted NYSE index for the market portfolio. The sample covers the time period from 1952:1 to 1987:12. 
Table 5

A. Residual Cash Elow Beta (RCEB) vs. Direct Cash Flow Beta (DCEB)

\begin{tabular}{lclllll}
\hline$\rho$ & Cash flow betas & market & rrate & D/P & infn & IPG \\
\hline 0.991 & RCFB & 0.759 & 1.394 & 0.116 & -1.647 & -0.330 \\
& DCFB & 0.614 & 1.415 & 0.111 & -1.512 & -0.274 \\
\hline 0.993 & RCFB & 0.750 & 1.400 & 0.118 & -1.667 & -0.341 \\
& DCFB & 0.623 & 1.462 & 0.110 & -1.587 & -0.292 \\
\hline 0.995 & RCFB & 0.741 & 1.407 & 0.120 & -1.690 & -0.353 \\
& DCFB & 0.631 & 1.514 & 0.108 & -1.672 & -0.313 \\
\hline 0.997 & RCFB & 0.730 & 1.416 & 0.121 & -1.717 & -0.366 \\
& DCFB & 0.641 & 1.574 & 0.106 & -1.770 & -0.337 \\
\hline
\end{tabular}

B. Correlation between Residual Cash Elow News and Direct Cash Flow News

\begin{tabular}{lllll}
\hline$\rho$ & 0.991 & 0.993 & 0.995 & 0.997 \\
\hline coñ. coefficieni & 0.922 & 0.926 & 0.930 & $0.93 j$ \\
\hline
\end{tabular}

Note: Both cash flow betas are calculated based on a one-lag VAR process for the state variables. The unit for each variable is percentage point per quarter for the market, percentage point per annum for rrate(real interest rate), basis point per annum for $D / P_{m}$, percentage point per annum for infn (inflation), percentage point per annum for IPG (industrial production growth, seasonally adjusted). In the calculation, we use $\rho^{*}=\rho^{3}$ instead of $\rho$ to make adjustment for the use of quarterly data. We use quarterly data covering the time period from 1952:Q1 to 1987:Q4. 
Table 6

Robustness to Specification

(Cash Flow Components of Observable Factor Betas for the Market Portfolio)

\begin{tabular}{|c|c|c|c|c|}
\hline Specifications & rrate & $\bar{D} / \mathrm{P}_{\mathrm{m}}$ & infn & IPG \\
\hline \multicolumn{5}{|l|}{ A. No asset pricing_restriction } \\
\hline$L=5$, VAR $L a g=1, \Omega$ unknown & 0.202 & -0.015 & -0.262 & 0.014 \\
\hline (same as above, drop 87:10-87:12) & 0.210 & -0.017 & -0.271 & 0.015 \\
\hline $\mathrm{L}=5$, VAR Lag $=1, \Omega$ known & 0.202 & -0.015 & -0.262 & 0.014 \\
\hline$L=5$, VAR $\mathrm{Lag}=2, \Omega$ known & 0.302 & -0.016 & -0.354 & 0.023 \\
\hline \multicolumn{5}{|l|}{ B. CAPM restriction } \\
\hline$L=5$, VAR Lag $=1, \Omega$ known & 0.231 & -0.035 & -0.320 & 0.035 \\
\hline$L=5$, VAR $L a g=2, \Omega$ known & 0.532 & -0.049 & -0.713 & 0.067 \\
\hline \multicolumn{5}{|c|}{ c. Unobservable factor medel restriction } \\
\hline $\mathrm{L}=5, \mathrm{~K}=1, \mathrm{VAR} \mathrm{Lag}=1, \Omega$ unknown & 0.195 & -0.010 & -0.258 & 0.016 \\
\hline $\mathrm{L}=5 . \mathrm{K}=1$. VAR $\mathrm{Lag}=1, \Omega$ known & 0.202 & -0.015 & -0.262 & 0.014 \\
\hline $\mathrm{L}=5, \mathrm{~K}=1$, VAR $\mathrm{Lag}=2, \Omega$ known & 0.302 & -0.015 & -0.355 & 0.022 \\
\hline \multicolumn{5}{|c|}{ D. Observable factor medel restriction } \\
\hline $\mathrm{L}=\mathrm{K}=5$, VAR $\mathrm{Lag}=1, \Omega$ known & 0.202 & -0.015 & -0.263 & 0.015 \\
\hline $\mathrm{L}=\mathrm{K}=5$, VAR $\mathrm{Lag}=2, \Omega$ known & 0.300 & -0.017 & .0 .353 & 0.023 \\
\hline
\end{tabular}

E. $x^{2}$-statistics for various medel restriction

$\begin{array}{lclll}\mathrm{L}=5, \text { VAR Lag=1, } \Omega \text { known } & 85.79 & \mathrm{df}=55 & \mathrm{P}=0.005 & \text { (CAPM) } \\ \mathrm{L}=5, \text { VAR Lag }=2, \Omega \text { known } & 133.68 & \mathrm{df}=110 & \mathrm{P}=0.062 & \text { (CAPM) } \\ \mathrm{L}=5, \mathrm{~K}=1, \text { VAR Lag=1, } \Omega \text { known } & 67.06 & \mathrm{df}=48 & \mathrm{P}=0.036 & \text { (unobservable factor) } \\ \mathrm{L}=5, \mathrm{~K}=1, \text { VAR Lag=2, } \Omega \text { known } & 111.53 & \mathrm{df}=108 & \mathrm{P}=0.388 & \text { (unobservable factor) } \\ \mathrm{L}=\mathrm{K}=5, \text { VAR Lag=1, } \Omega \text { known } & 30.85 & \mathrm{df}=35 & \mathrm{P}=0.668 & \text { (observable factor) } \\ \mathrm{L}=\mathrm{K}=5, \text { VAR Lag=2, } \Omega \text { known } & 61.96 & \mathrm{df}=70 & \mathrm{P}=0.742 & \text { (observable factor) }\end{array}$

Note: $\mathrm{L}$ is the number of state variables in the economy. $K$ is the number of systematic factors in the factor model $\Omega$ is the variance-covariance matrix for innovations to the economic state variables and unexpected portfolio excess returns. The statistics in this table are estimated based on excess returns on the twelve industrial portfolios and the five economic state variables. 


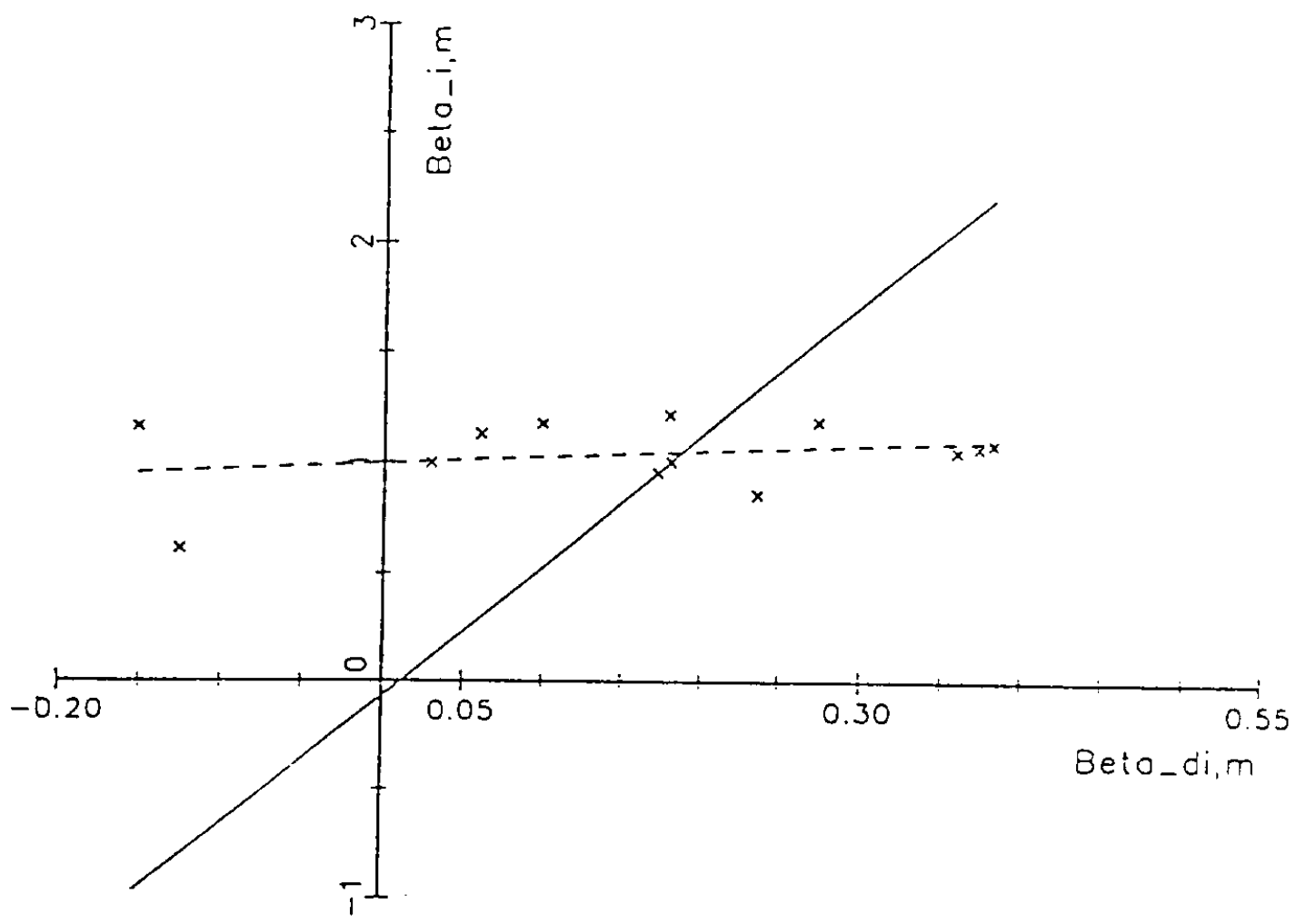

Figare 1: Overall Market Beta and Cash Flow Market Beta for Industral Portfolios

The torizoniai axis stowis ine mariei beta of an asset's cash fiow news. $\hat{p}_{d i, m}$. The vertical axis shows the asset's overall market beta. $\beta_{i, m}$. The solid straight line is the relationship between the two implied by the CAPM, equation (2.12) in the text:

$$
\beta_{i, m}=\left(1+\beta_{+m, m}\right)^{-1}\left(\beta_{d i, m}-\beta_{r, m}\right)
$$

The figure assumes $\beta_{e m, m}=-0.832$ and $\beta_{r, m}=0.012$, based on estimates calculated for the period 1952-87. The scatterplot provides the empirical relationship between $\beta_{\mathrm{di}} \mathrm{m}$ and $\beta_{i, m}$. The dashed line is the regression line for the scatter points. 


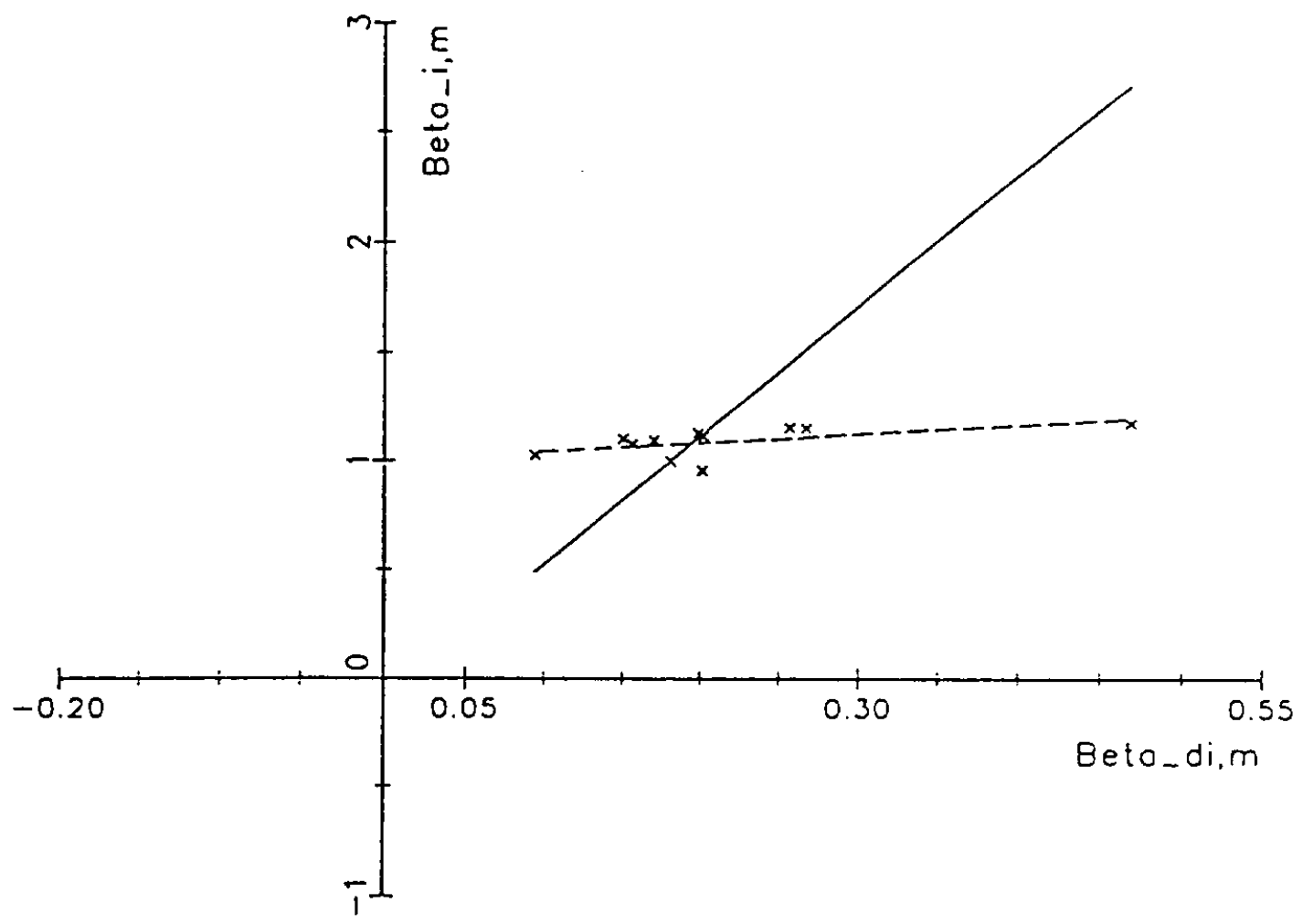

Figure 2: Overall Market Beta and Cash Flow Market Beta for Size Portfolios

The horizontal axis shows the market beta of an asset's cash flow news. $\beta_{\text {di.m. }}$. The vertical axis shows the asset's overall market beta. $\beta_{i, m}$. The solid straight line is the relationship between the two implied by the CAPM, equation (2.12) in the text:

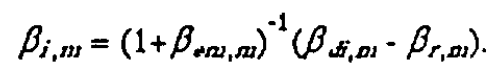

The figure assumes $\beta_{\mathrm{em}, \mathrm{m}}=-0.832$ and $\beta_{r, m}=0.012$, based on estimates calculated for the period 1952-87. The scalterplot provides the empirical relationship between $\beta_{\text {di.m }}$ and $\beta_{i, m}$. The dashed line is the regression line for the scatter points. 